\title{
Aldose reductase mediates endothelial cell dysfunction induced by high uric acid concentrations
}

Zhiyong Huang ${ }^{1,2+}$, Quan Hong ${ }^{1 \dagger}$, Xueguang Zhang ${ }^{3}$, Wenzhen Xiao ${ }^{3}$, Liyuan Wang ${ }^{1}$, Shaoyuan Cui', Zhe Feng ${ }^{1}$, Yang LV ${ }^{1}$, Guangyan Cai ${ }^{1}$, Xiangmei Chen ${ }^{1}$ and Di Wu ${ }^{1 *}$

\begin{abstract}
Background: Uric acid (UA) is an antioxidant found in human serum. However, high UA levels may also have pro-oxidant functions. According to previous research, aldose reductase (AR) plays a vital role in the oxidative stress-related complications of diabetes. We sought to determine the mechanism by which UA becomes deleterious at high concentrations as well as the effect of AR in this process.

Method: Endothelial cells were divided into three groups cultured without UA or with $300 \mu \mathrm{M}$ or $600 \mu \mathrm{M}$ UA. The levels of total reactive oxygen species (ROS), of four ROS components, and of NO and NOX4 expression were measured. Changes in the above molecules were detected upon inhibiting NOX4 or AR, and serum $\mathrm{H}_{2} \mathrm{O}_{2}$ and $v W F$ levels were measured in vivo.

Results: Increased AR expression in high UA-treated endothelial cells enhanced ROS production by activating NADPH oxidase. These effects were blocked by the AR inhibitor epalrestat. $300 \mu \mathrm{M}$ UA decreased the levels of the three major reactive oxygen species (ROS) components: $\mathrm{O}_{2} \cdot-\cdot \cdot \mathrm{OH}$, and ${ }^{1} \mathrm{O}_{2}$. However, when the UA concentration was increased, both $\mathrm{O}_{2} \cdot$ - levels and downstream $\mathrm{H}_{2} \mathrm{O}_{2}$ production significantly increased. Finally, an $\mathrm{AR}$ inhibitor reduced $\mathrm{H}_{2} \mathrm{O}_{2}$ production in hyperuricemic mice and protected endothelial cell function.

Conclusions: Our findings indicate that inhibiting AR or degrading $\mathrm{H}_{2} \mathrm{O}_{2}$ could protect endothelial function and maintain the antioxidant activities of UA. These findings provide new insight into the role of UA in chronic kidney disease.
\end{abstract}

Keywords: Aldose reductase, Endothelial cell dysfunction, Uric acid, Reactive oxygen species, Hyperuricemia, CKD

\section{Background}

Uric acid (UA) is the final enzymatic product in the degradation of purine nucleosides and free bases in humans and the great apes [1-3]. UA is a powerful antioxidant that scavenges singlet oxygen $\left({ }^{1} \mathrm{O}_{2}\right)$ molecules, oxygen radicals, and peroxynitrite $\left(\mathrm{ONOO}^{-}\right)$molecules. $\mathrm{UA}$ also chelates transition metals to reduce ion-mediated ascorbic acid oxidation [4-7]. UA is responsible for

\footnotetext{
* Correspondence: wudi@301hospital.com.cn

${ }^{\dagger}$ Equal contributors

'Department of Nephrology, Chinese PLA General Hospital, Chinese PLA Institute of Nephrology, State Key Laboratory of Kidney Diseases, National Clinical Research Center of Kidney Diseases, Beijing 100853, People's Republic of China

Full list of author information is available at the end of the article
}

approximately $50 \%$ of serum antioxidant activity [2, 4]. However, in vivo and cellular studies have demonstrated that depending on its chemical microenvironment, UA may also be a pro-oxidant [8]. Strong epidemiological evidence suggests that the prevalence of gout and hyperuricemia is increasing worldwide [9]. High UA levels are strongly associated with and often predict the development of hypertension, visceral obesity, insulin resistance, dyslipidemia, type II diabetes, kidney disease, and cardiovascular events [10, 11]. Although endothelial dysfunction generally occurs in the initial stages of these diseases, few studies on the effect of UA on human endothelial cells have been performed [12]. UA dosedependently decreases nitric oxide $(\mathrm{NO})$ production in 
intact bovine aortic endothelial cells [13], and hyperuricemia induces endothelial dysfunction via mitochondrial $\mathrm{Na}$ ${ }^{+} / \mathrm{Ca}^{2+}$ exchange-mediated mitochondrial calcium overload [14]. However, how the effects of UA become deleterious at high concentrations is unknown. Although the pathogenesis of these diseases is extremely complex and incompletely understood, oxidative stress clearly plays a central role. The urate oxidant-antioxidant paradox led us to investigate the point at which urate becomes an oxidant and the pathway through which this occurs. Although UA may have protective effects under certain conditions [15, 16], it cannot scavenge all radicals. Additionally, UA and/ or its downstream radicals can trigger intracellular oxidant production via the ubiquitous NADPH oxidase-dependent pathway, thereby resulting in oxidative stress.

Aldose reductase (AR) is the rate-limiting enzyme in the polyol pathway, and NADPH acts as a cofactor [17]. AR plays an important role in the pathogenesis of diabetic complications [18] and atherosclerosis [19]. In diabetic rats, AR expression was increased, and inhibiting AR ameliorated renal function [20]. The AR inhibitor epalrestat suppresses the progression of diabetic complications such as retinopathy, nephropathy and neuropathy [21]. Genetic AR deficiency also prevented the progress of diabetic nephropathy [22]. The elevation of AR may be related to higher oxidative stress levels in diabetic rats [23]. In our previous research, AR expression was increased in endothelial cells treated with high uric acid concentrations [24]. Increased substrate flux via AR leads to increased ROS production, cell injury, apoptosis, altered ion regulation, and mitochondrial dysfunction [25-31], and increased ROS production is associated with NADPH oxidase activation [32-34].

In this study, we detected the different ROS types generated in HUVECs cultured with different UA concentrations as well as the changes in ROS production upon transfecting HUVECs with siRNA against AR. We then investigated the role of AR in UA-induced endothelial injury in vitro and in vivo. Our results suggest a novel mechanism underlying the endothelial dysfunction caused by high UA levels.

\section{Methods}

\section{Cell culture and uric acid preparation}

Human umbilical vein endothelial cells (HUVECs) were purchased from YRbio (Cat\#NC006, Changsha, China) and cultured in RPMI-1640 media supplemented with $10 \%$ fetal bovine serum (FBS) at $37{ }^{\circ} \mathrm{C}$ in a humidified incubator in a $5 \% \mathrm{CO}_{2}$ atmosphere.

Uric acid was purchased from Sigma-Aldrich (Carlsbad, CA). Uric acid powder was dissolved in a $1 \mathrm{~mol} / \mathrm{L}$ $\mathrm{NaOH}$ solution at a concentration of $40 \mathrm{mmol} / \mathrm{L}$. Then, the uric acid solution was added to the serum containing medium at a final concentration and at a pH 7.2-7.4.

\section{Intracellular reactive oxygen species (ROS) assays}

Cells were seeded onto $35-\mathrm{mm}$ confocal dishes (with a cover glass) and classified into control, normal uric acid (UA), and high uric acid (HUA) groups $(n=3)$. Cells in the UA and HUA groups were cultured in medium containing 300 or $600 \mu \mathrm{M}$ uric acid, respectively, for $24 \mathrm{~h}$ followed by incubation with the total oxidative stress indicator chloromethyl derivative dichlorodihydrofluorescein diacetate $\left(\mathrm{CM}-\mathrm{H}_{2}\right.$ DCFDA, Beyotime, Nanjing China, $5 \mu \mathrm{M}$ ) for $30 \mathrm{~min}$ in the dark at $37^{\circ} \mathrm{C}$. After three washes in PBS, green fluorescence was visualized using a laser scanning confocal microscope at an excitation wavelength of $488 \mathrm{~nm}$ and an emission wavelength of $515 \mathrm{~nm}$.

Before HUA treatment, the HUA group was pretreated with $0.5 \mathrm{mM}$ apocynin (Santa Cruz Biotechnology) or $0.1 \mu \mathrm{M}$ epalrestat (Santa Cruz Biotechnology). Pyocyanin (100 $\mu \mathrm{M}$; Sigma) was used as a positive control in the comparisons of ROS production.

\section{Detection of intracellular ROS components}

For the total intracellular ROS levels, method was referenced previously by the oxidant-sensing fluorescent probe CM-H 2 DCFDA [14]. Briefly, this probe was loaded into previously subcultured HUVEC-Cs at a final concentration of $10 \mu \mathrm{mol} / \mathrm{L}$, and the cells were then cultured for $30 \mathrm{~min}$ at $37^{\circ} \mathrm{C}$. After incubation, the culture medium was washed twice with PBS and analyzed by laser confocal microscopy with an excitation wavelength of $488 \mathrm{~nm}$ and an emission wavelength of $515 \mathrm{~nm}$.

The detection of intracellular ROS components occurred as follows. For $\mathrm{O}_{2}^{--}$(Mitochondrial): cells were incubated with $4 \mu \mathrm{mol} / \mathrm{L}$ Mito-SOX Red (Invitrogen) in the dark at $37^{\circ} \mathrm{C}$ for $10 \mathrm{~min}$, and red fluorescence was observed at an excitation wavelength of $510 \mathrm{~nm}$ and an emission wavelength of $580 \mathrm{~nm}$. For $\mathrm{H}_{2} \mathrm{O}_{2}$ : cells were incubated with $30 \mu \mathrm{mol} / \mathrm{L}$ BES- $\mathrm{H}_{2} \mathrm{O}_{2}$ (Seebio, China) in the dark at $37^{\circ} \mathrm{C}$ for $1 \mathrm{~h}$, and green fluorescence was observed at an excitation wavelength of $485 \mathrm{~nm}$ and an emission wavelength of $515 \mathrm{~nm}$. For $\cdot \mathrm{OH}$ : cells were incubated with $100 \mu \mathrm{mol} / \mathrm{L}$ proxylfluorescamine (Invitrogen) in the dark at $37{ }^{\circ} \mathrm{C}$ for $30 \mathrm{~min}$, and green fluorescence was observed at an excitation wavelength of $488 \mathrm{~nm}$ and an emission wavelength of $520 \mathrm{~nm}$. For ${ }^{1} \mathrm{O}_{2}$ : cells were incubated with $20 \mu \mathrm{mol} / \mathrm{L}$ trans-1-( $\left(2^{\prime}\right.$-methoxyvinyl)pyrene (Invitrogen) in the dark at $37{ }^{\circ} \mathrm{C}$ for $10 \mathrm{~min}$, and blue fluorescence was observed at an excitation wavelength of $405 \mathrm{~nm}$ and an emission wavelength of $460 \mathrm{~nm}$. For $\mathrm{ONOO}^{-}$: cells were incubated with $10 \mu \mathrm{mol} / \mathrm{L}$ dihydrorhodamine123 (Santa Cruz) in the dark at $37^{\circ} \mathrm{C}$ for $30 \mathrm{~min}$, and green fluorescence was observed at an excitation wavelength of $488 \mathrm{~nm}$ and an emission wavelength of $520 \mathrm{~nm}$. 


\section{Generation of inducible and stable cell lines}

Reverse transcription was carried out on human kidney RNA with Superscript II reverse transcriptase, according to the manufacturer's instructions. The full-length human NOX4 was amplified by PCR using the primers NOX4_F, 5'-GGGGACAAGTTTGTACAAAAAAGCAGGCTTCAC CATGGCTGTGTCCTGGAGG-3', and NOX4_R, 5' -GGG GACCACTTTGTACAAGAAAGCTGGGTCTCA GCTG AAAGACTCTTTATTGTATTC-3'. The PCR product was cloned into a pcDNA3.1 vector according to the manufacturer's instructions, obtained pcDNA-NOX4. HUVECs were transfected with the pcDNA-NOX4 plasmid using Lipofectamine 2000 (Invitrogen). Clones were selected 1016 days after transfection using $400 \mu \mathrm{g} / \mathrm{ml}$ neomycin (G418) to obtain HUVECs stably expressing NOX4.

\section{Measurement of nitric oxide levels in culture supernatants or serum}

Before treatment with chemicals or UA, media were replaced with Dulbecco's modified Eagle's medium (DMEM). The supernatant or serum was centrifuged and subjected to NO level evaluation using the Nitric Oxide Assay Kit (Applygen Technologies, China) according to the manufacturer's instructions. The end-point measured formula was $\mathrm{NO}_{2}^{-}$.

\section{Real-time PCR}

RNA was extracted from tissues and cells using TRIzol reagent (Invitrogen) and reverse transcribed into cDNA using M-MLV reverse transcriptase (Invitrogen). The cDNA was used as a template in quantitative real-time PCR reactions performed using SYBR green I PCR Master Mix and an ICycler system (Bio-Rad). The following primers were designed from the full-length AR and Nox4 mRNA sequences and synthesized by SBS Biotechnology Corporation (Beijing, China): AR sense, 5' - CCTATGGCCAAGGACA CACT-3' and antisense, 5'-CTGGTCTCAGGCAAGGAA AG-3'; NOX4 sense, 5' -TTGCCTGGAAGAACCCAAGT $-3^{\prime}$ and antisense, 5' - TCCGCACAATAAAGGCACAA-3'. As an internal control, mouse GAPDH was amplified using the following primers: sense, 5 '-GGCATGGACTGTGGTCATGAG- 3 ' and antisense, $5^{\prime}$-TGCACCACCAACTGCTTAGC-3'. Relative expression (fold change vs. control) was quantified using the $2^{-\Delta \Delta C t}$ method.

\section{Western blotting}

For Western blotting, proteins were extracted from tissues or cells using RIPA lysis buffer $(50 \mathrm{mM}$ Tris- $\mathrm{HCl}$, $\mathrm{pH} 7.5,150 \mathrm{mM} \mathrm{NaCl}, 0.5 \%$ deoxycholate, $1 \%$ Nonidet P-40, 0.1\% SDS, $1 \mathrm{mM}$ PMSF, and protease cocktail at $1 \mu \mathrm{g} / \mathrm{ml})$. Protein concentrations were measured using a BCA kit (Pierce). Protein samples $(60 \mu \mathrm{g}$ per lane) were separated by $12 \%$ SDS-PAGE and transferred to nitrocellulose (NC) membranes. After staining with Ponceau S, the membranes were incubated overnight at $4{ }^{\circ} \mathrm{C}$ in $5 \%$ non-fat milk followed by incubation with a primary antibody against AR (Santa Cruz Biotechnology) or $\beta$-actin (Sigma). Immunoreactive bands were visualized using ECL reagent (Santa Cruz Biotechnology) according to the manufacturer's instructions and were then exposed to X-ray film. Protein band intensities were quantified using the Quantity One software (Bio-Rad). The assay was repeat 3 times.

\section{Aldose reductase activity assays}

AR activity was measured spectrophotometrically as previously described $[35,36]$. Briefly, AR activity was measured as the decrease in the absorbance of NADPH at $340 \mathrm{~nm}$ using DL-glyceraldehyde as the substrate. The assay mixture contained $30 \mathrm{mM}$ potassium phosphate buffer (pH 6.5), $5 \mathrm{mM}$ DL-glyceraldehyde, $0.2 \mathrm{M}$ ammonium sulfate, and $1.0 \mathrm{mM}$ NADPH. The results are presented as $\mu \mathrm{mol} \mathrm{NADPH} \cdot \mathrm{min}-1 \cdot \mathrm{g}-1$ protein. All reagents were from Sigma. The assay was repeat 3 times.

\section{Establishment of hyperuricemic mouse models}

Hyperuricemic mouse models were established as described by Yang et al. [37] with slight modifications. The animal protocol was reviewed and approved by the Institutional Animal Care and Use Committee of the Chinese PLA General Hospital. Wild-type C57BL/6 mice obtained from the Experimental Animal Center of the Academy of Military Medical Sciences (China) were used as controls. The mice were housed in temperature-controlled cages on a 12-h light-dark cycle and given free access to water and normal chow. After one week of breeding for adaptation, the mice were grouped into control $(n=6)$ and hyperuricemic model $(n=24)$ groups. Mice were intraperitoneally injected with $250 \mathrm{mg} / \mathrm{Kg} \cdot \mathrm{d}$ oxonic acid potassium salt (Sigma) and $250 \mathrm{mg} / \mathrm{Kg} \cdot \mathrm{d}$ uric acid (Sigma). After receiving intraperitoneal injections for 3 days, the hyperuricemic model group was sub-classified into hyperuricemic mice $(n=6)$, hyperuricemic mice treated with epalrestat $(100 \mathrm{mg} / \mathrm{Kg} \cdot \mathrm{d}$, Dyne, China) $(n=6)$, and hyperuricemic mice treated with polyethylene glycol catalase (PEG-catalase, $12000 \mathrm{U} / \mathrm{Kg} \cdot \mathrm{d}$, Sigma) $(n=6)$. The antioxidant treatments PEG-catalase and epalrestat were intragastrically administered. After 10 days of modeling, the levels of UA, $\mathrm{NO}, \mathrm{H}_{2} \mathrm{O}_{2}$, and von Willebrand factor (vWF) in the blood were evaluated.

\section{Measurement of serum UA, $\mathrm{H}_{2} \mathrm{O}_{2}$ and vWF levels}

The serum UA level was assayed using an enzymatic method that measures the end production of quinonimine using an automatic biochemical analyzer (Hitachi, Japan). Serum $\mathrm{H}_{2} \mathrm{O}_{2}$ levels were assayed using a hydrogen peroxide assay kit (NJJCbio, Nanjing, China) with the end formula $\mathrm{Mn}^{2+}$. vWF was detected using a von Willebrand Factor ELISA kit. 


\section{Statistical analyses}

All data are expressed as the means \pm SD. Mean comparisons among multiple groups were conducted using oneway analysis of variance (ANOVA). Comparisons of the means between two groups were conducted using randomized controlled $t$-tests. A $p$ value $<0.05$ was considered statistically significant.

\section{Results}

High UA increased intracellular ROS production, AR activity and endothelial cell impairment but decreased NO release

To confirm the impairment of endothelial cells by UA treatment, we evaluated the effect of different UA concentrations on ROS production and $\mathrm{NO}$ release in

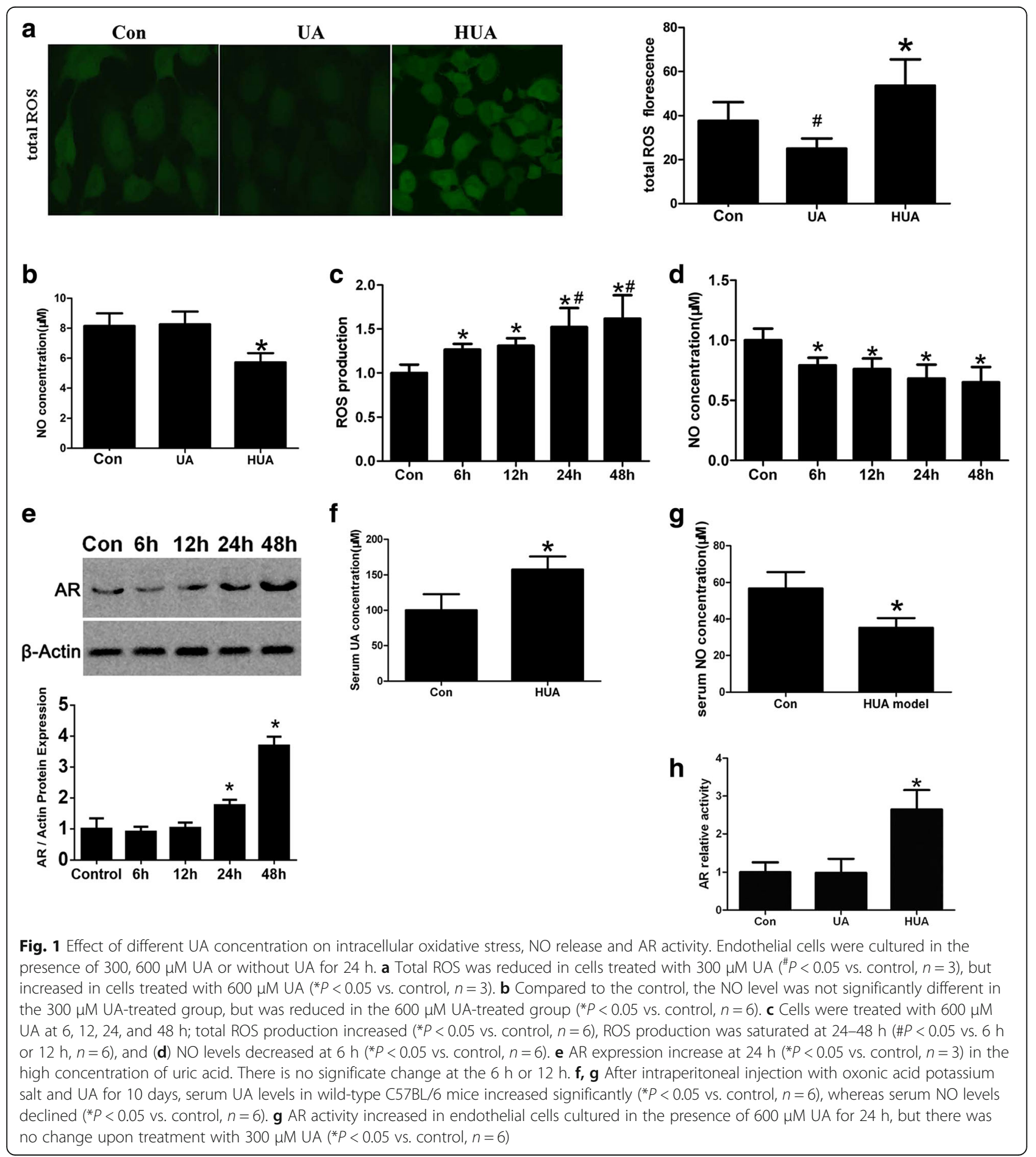


HUVECs UA $(300 \mu \mathrm{M})$ reduced total ROS levels in endothelial cells, whereas high UA $(600 \mu \mathrm{M})$ treatment increased intracellular ROS production (Fig. 1a). NO release was reduced after high UA treatment in vitro with the turning point of $500 \mu \mathrm{mol} / \mathrm{L}$, An additional file shows this in more detail [see Additional file 1] but unchanged after UA treatment (Fig. 1b). Additionally, total ROS production increased and NO levels decreased in a time-dependent manner in cells treated with high UA, AR protein expression increased at $24 \mathrm{~h}$ and $48 \mathrm{~h}$ of high concentration uric acid treated (Fig. 1c, d and e). In male hyperuricemic C57BL/6 mice after modeling in vivo serum UA levels significantly increased (Fig. 1f), whereas NO levels decreased (Fig. 1g). Furthermore, AR activity increased in endothelial cells (Fig. 1h). Our results showed that AR activity increased upon treatment with high UA concentrations but not with normal UA concentrations.

High UA increased AR expression via p38/MAPK pathway In order to assay how UA trigger AR expression. P38 and extracellular signal-regulated kinase (ERK) 42/44 MAPK phosphorylation are involved in the UA-induced cell proliferation and activation in the UA-induced HUVEC [12]. Therefore we determined the effect of blocking p38 and ERK44/42 MAPK in UA-induced AR expression using specific inhibitors of the p38 (SB203580, $5 \mu \mathrm{M}$ ) and ERK44/42 (PD 98059, $10 \mu \mathrm{M}$ ) MAPK pathways respectively. Also, we used the organic anion transporter inhibitor, probenecid (Sigma-Aldrich, St. Louis, MO, USA), to block the uric acid transport into cells. We found AR expression increased when
HUVECs were treated with high UA for 48 h, p38 and p-ERK42/44 were activated simultaneously [Fig. 2a]. When blocking p38 and MAPK by specific inhibitor SB203580 and PD 98059 respectively, or blocking the organic anion transporter that could transport uric acid into intracellular by probenecid, AR protein expression decreased [Fig. 2b].

\section{Increased AR expression enhances ROS production by activating NADPH oxidase}

NOX4 is the main NOX as well as the main source of ROS in endothelial cells under oxidative stress [38-40]. NOX4 mRNA and protein expression levels increased in endothelial cells following challenge with high UA (Fig. 3a and b), but not NOX2, An additional file shows this in more detail [see Additional file 2]. However, when pretreated with the NOX inhibitor apocynin, ROS production induced by high UA levels was reduced (Fig. 3c). However, NOX4 expression was downregulated following pretreatment with the AR inhibitor epalrestat before high UA treatment, (Fig. 3a and b), suggesting that the enhanced AR expression induced by high UA activates NOX, thereby upregulating ROS expression and ultimately impairing endothelial cells. The AR inhibitor enhanced NO production compared with that in the high UA group (Fig. 3d), suggesting that inhibiting ROS production protected endothelial cells. However, when NOX4 was overexpressed in combination with AR knockdown, high UA treatment significantly decreased ROS production compared with that of cells overexpressing NOX4 alone. Furthermore, NO secretion concomitantly increased (Fig. 3e-g).

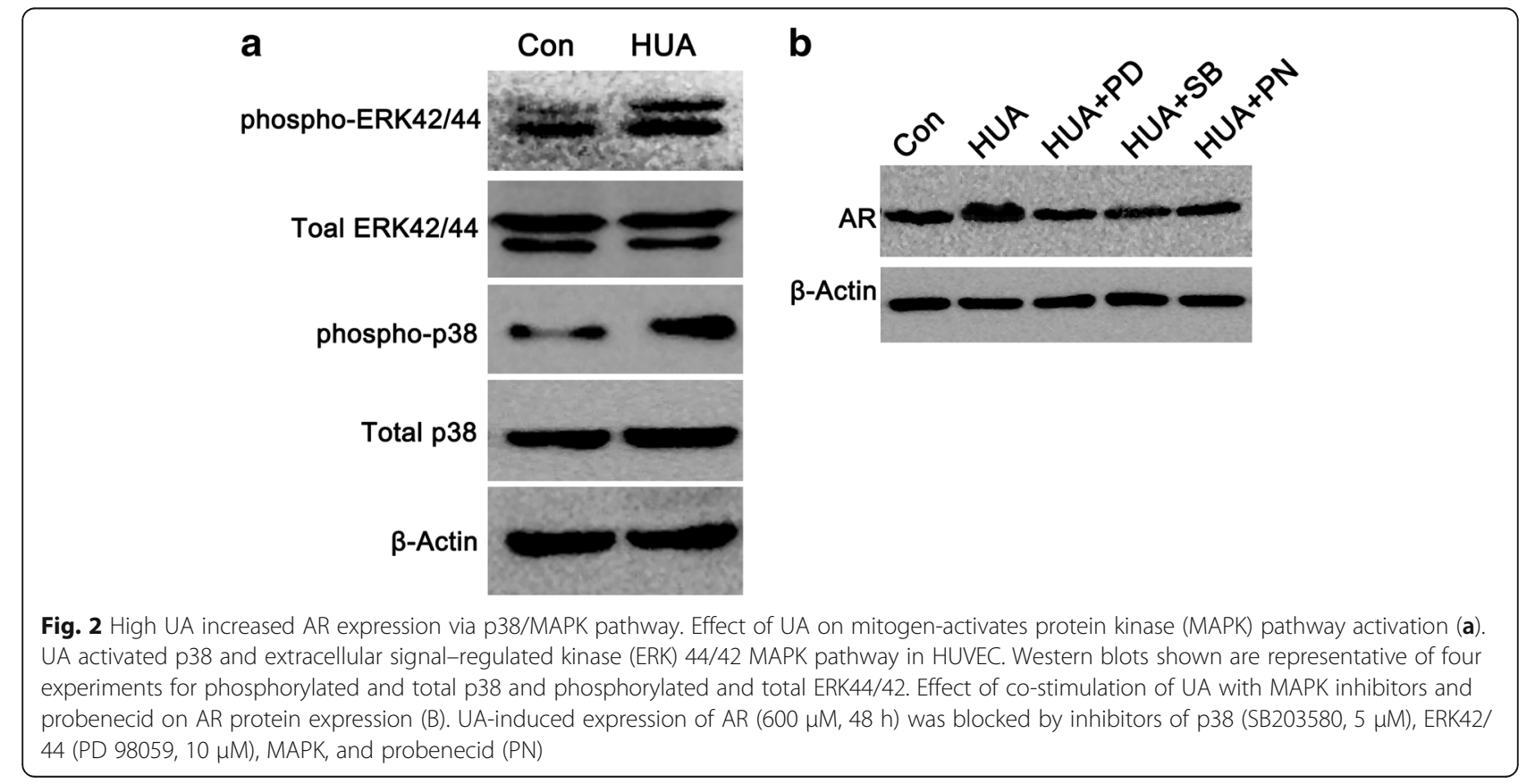



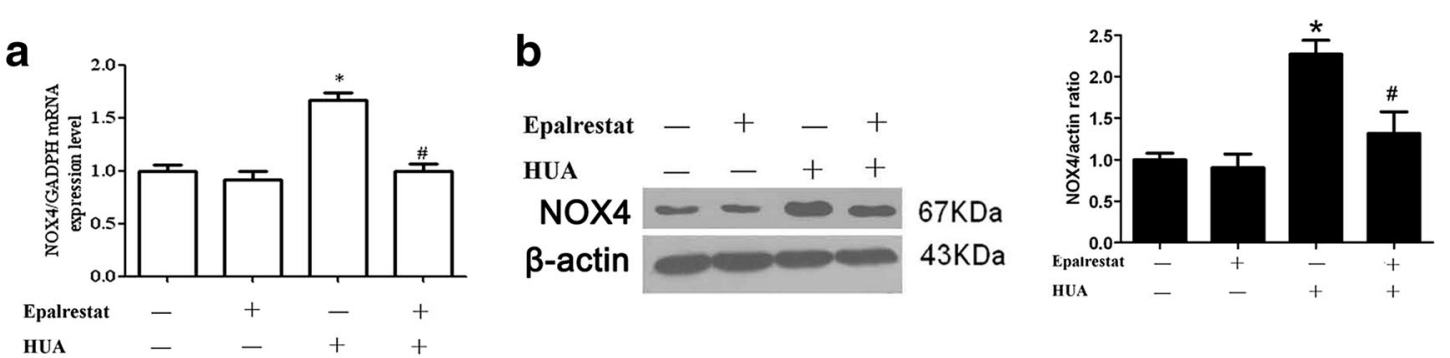

c
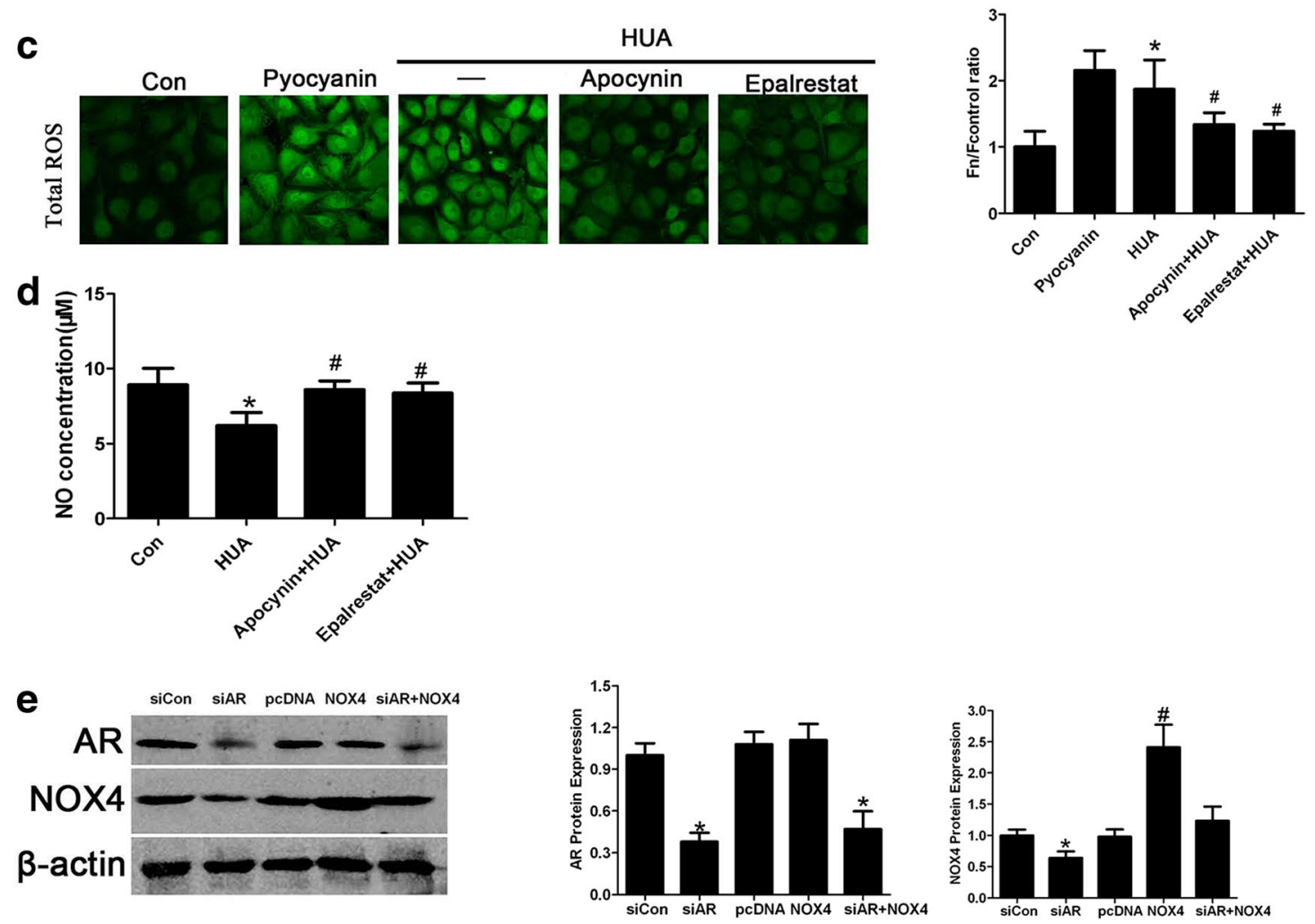

f

SiAR
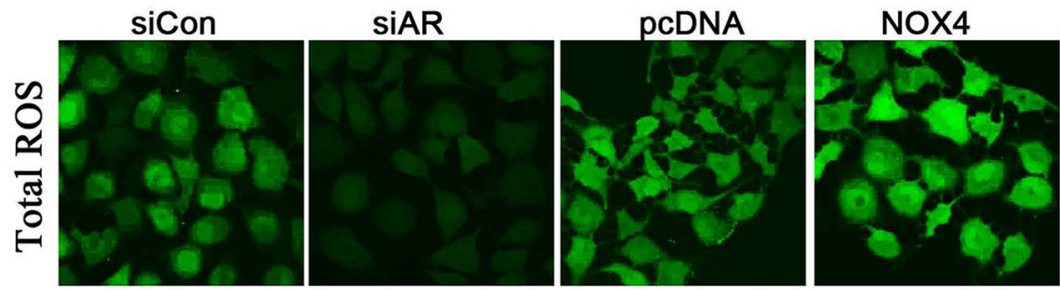

siAR+NOX4
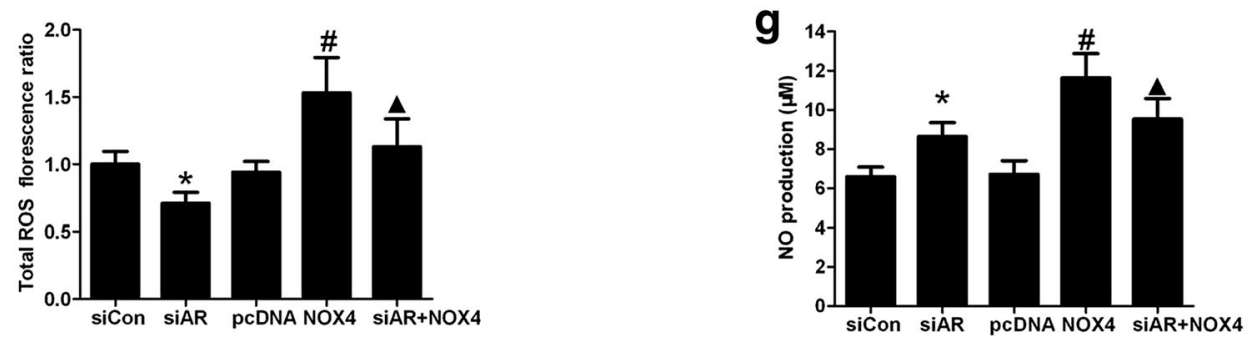

Fig. 3 (See legend on next page.) 
(See figure on previous page.)

Fig. 3 The AR inhibitor alleviated oxidative stress and impaired HUVECS by inhibiting NADPH oxidase activity. a and b Nox4 production was up-regulated in endothelial cells cultured in the presence of $600 \mu \mathrm{M}$ UA for $24 \mathrm{~h}\left({ }^{*} P<0.05 \mathrm{vs}\right.$. control, $\left.n=6\right)$, but down-regulated in Epalrestat + HUA cells pretreated with epalrestat $(0.1 \mu \mathrm{M})$ for $30 \mathrm{~min}$, followed by incubation with UA $(600 \mu \mathrm{M})$ for $24 \mathrm{~h}\left({ }^{\#} P<0.05 \mathrm{vs}\right.$. HUA group, $\left.n=6\right)$. c ROS production increased in endothelial cells incubated with UA $(600 \mu \mathrm{M})$ for $24 \mathrm{~h}\left({ }^{*} P<0.05\right.$ vs. control, $\left.n=6\right)$, was similar to that in cells treated with pyocyanin, decreased in endothelial cells when pretreated with apocynin/epalrestat ( $P<0.05$ vs. HUA group, $n=6)$, and was reduced significantly in cells pretreated with the AR inhibitor epalrestat $\left({ }^{\dagger} P<0.05\right.$, Apocynin + HUA group vs. Epalrestat $+H U A$ group, $\left.n=6\right)$. $\mathbf{d}$ NO levels in supernatant in the Epalrestat + HUA group were enhanced compared to those in the high UA group after endothelial cells were pretreated with epalrestat for 30 min followed by UA $(600 \mu \mathrm{M})$ for $24 \mathrm{~h}\left({ }^{*} P<0.05\right.$ vs. HUA group, $\left.n=6\right)$. e- $\mathbf{g}$ Cells were transfected with siRNA or pCDNA3-NOX4, and treated with high uric acid for $24 \mathrm{~h}$. AR siRNA knocked-down AR protein expression and downregulated NOX4 expression ( ${ }^{*} P<0.05$ vs. siCon group, $n=6$ ). ROS production decreased and NO production increased ( ${ }^{*} P<0.05$ vs. siCon group, $n=6$ ). However, overexpression of NOX4 did not affect AR. If cells were treated with AR RNAi and overexpressed NOX4, ROS production and NO concentration significantly decreased and increased, respectively, compared to the NOX4 overexpression group $(\boldsymbol{\Lambda} P<0.05, n=6)$

High UA impaired endothelial cells by enhancing $\mathrm{H}_{2} \mathrm{O}_{2}$ production but inhibited other ROS components

We then assessed the production of four ROS components after treatment with various UA concentrations. UA partially eliminated superoxide anion $\left(\mathrm{O}_{2}^{--}\right),{ }^{1} \mathrm{O}_{2}$, and hydroxyl radical $(. \mathrm{OH})$ production and subtly increased $\mathrm{H}_{2} \mathrm{O}_{2}$ production. However, high UA treatment increased $\mathrm{O}_{2}^{*-}$ and $\mathrm{H}_{2} \mathrm{O}_{2}$ production but reduced ${ }^{1} \mathrm{O}_{2}$ and . $\mathrm{OH}$ production (Fig. 4a).

After high UA treatment, $\mathrm{O}_{2}^{--}$and $\mathrm{H}_{2} \mathrm{O}_{2}$ levels increased. Although $\mathrm{O}_{2}^{*-}$ is highly dynamic, it soon became disproportionate to $\mathrm{H}_{2} \mathrm{O}_{2}$. Therefore, we inferred that $\mathrm{H}_{2} \mathrm{O}_{2}$ is the major ROS contributor to endothelial cell impairment induced by high UA treatment. $\mathrm{H}_{2} \mathrm{O}_{2}$ levels significantly decreased in endothelial cells pretreated with epalrestat followed by high UA treatment, but $\mathrm{ONOO}^{-}$levels did not change (Fig. 4b). When PEGcatalase was applied to eliminate intracellular $\mathrm{H}_{2} \mathrm{O}_{2}$, total intracellular ROS levels were reduced, and $\mathrm{NO}$ levels increased compared with the high UA group that did not receive PEG-catalase treatment (Fig. 4c, d).

\section{PEG-catalase and AR inhibitor epalrestat reduce $\mathrm{H}_{2} \mathrm{O}_{2}$ production in hyperuricemic mice and effectively protect mouse endothelial cell function}

Elevated $\mathrm{H}_{2} \mathrm{O}_{2}$ can lead to vascular endothelial dysfunction [41]. $\mathrm{H}_{2} \mathrm{O}_{2}$ production increased in endothelial cells after high UA treatment in vitro (Fig. 3a). Upon endothelial dysfunction, cells release more vWF, which is a marker of endothelial dysfunction [42-44]. To estimate vascular endothelial function in vivo, we detected serum vWF concentrations. Serum $\mathrm{H}_{2} \mathrm{O}_{2}$ and vWF (Fig. 5b d) levels increased in the hyperuricemic model, while the NO concentration decreased. We concluded that $\mathrm{AR}, \mathrm{O}_{2}^{--}$, and $\mathrm{H}_{2} \mathrm{O}_{2}$ are the major contributors to impaired endothelial cell function. Inhibiting these could reduce the number of impaired endothelial cells induced by high UA treatment. After treatment with PEG-catalase or epalrestat, serum $\mathrm{H}_{2} \mathrm{O}_{2}$ (Fig. 5b) and vWF (Fig. 5c) levels decreased compared with those of the untreated group, while NO concentration increased (Fig. 5d). Based on the PEG-catalase treatment results, $\mathrm{H}_{2} \mathrm{O}_{2}$ may be the final ROS product responsible for endothelial cell impairment. Our data suggest that PEG-catalase and epalrestat decrease $\mathrm{H}_{2} \mathrm{O}_{2}$ production, thereby protecting endothelial function.

\section{Discussion}

Uric acid (UA), which is generated in mammalian systems as an end product of purine metabolism, is the most abundant antioxidant in human plasma and possesses free radical scavenging properties. In humans and other higher primates, uric acid is the final compound of purines catabolism, but all other mammals converts uric acid to allantoin with enzyme uricase which is deficient in humans and other higher primates [2], and is the main reason why serum UA levels in adult males are $350 \mu \mathrm{mol} / \mathrm{L}$, compared with the majority of mammals who have UA levels $<30-60 \mathrm{mg} / \mathrm{dl}$ [45]. Evidence has demonstrated Western diet could elevate serum uric acid [46]. However, it may also act as a pro-oxidant under oxidative stress conditions. Markedly increased UA levels cause gout and nephrolithiasis [47], and high UA concentrations are also associated with an increased risk of developing cardiovascular disease (CVD), particularly hypertension, obesity/metabolic syndrome, and kidney disease [10, 11, 48-51]. Jia et al. verified hyperuricemia is related with the development of obesity/ metabolic cardiomyopathy [46]. However, the role of UA in CVD pathogenesis is still debated. UA is one of the most important antioxidants in body fluids and effectively eliminates ROS [52]. Other risk factors exist in CVD patients in addition to the superoxide generation that accompanies UA production by xanthine oxidoreductase [53]. Whether UA is a causative risk factor or plays a protective role with respect to its antioxidant properties is not known $[54,55]$. The mechanism (s) by which UA acts as a "double-edged sword" remain to be determined.

Mounting evidence indicates that hyperuricemia induces heart and kidney injury by promoting free radical generation and subsequent endothelial dysfunction [56], which are regulated by $\mathrm{NO}$ bioavailability and activity 


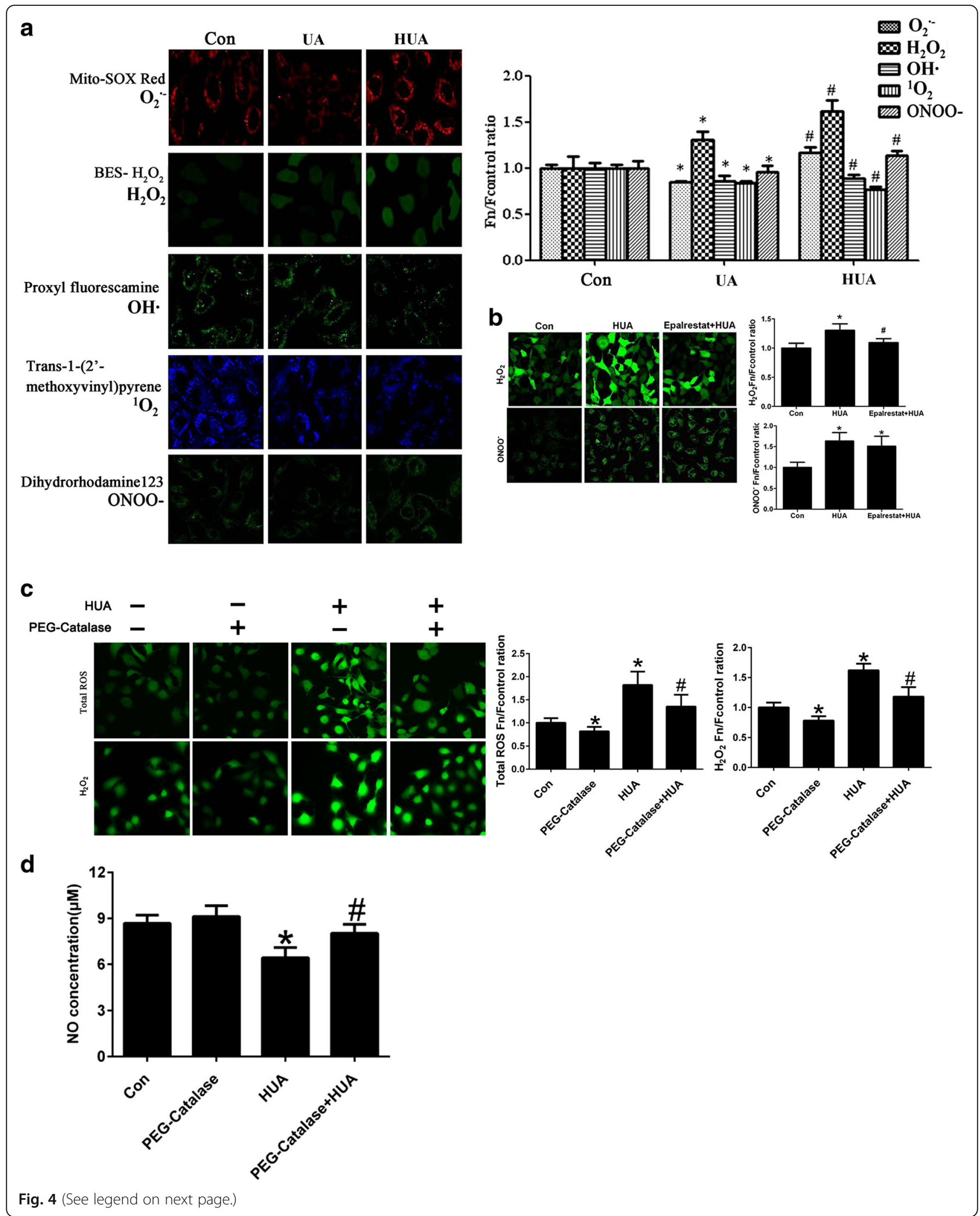


(See figure on previous page.)

Fig. $4 \mathrm{H}_{2} \mathrm{O}_{2}$ production increased in endothelial cells treated with various concentrations of $U A$, and impaired endothelial cells were reduced after elimination of $\mathrm{H}_{2} \mathrm{O}_{2}(\mathrm{~A}) \mathrm{O}_{2}^{-},{ }^{1} \mathrm{O}_{2}, \cdot \mathrm{OH}$, and $\mathrm{ONOO}^{-}$levels decreased in endothelial cells $\left({ }^{*} P<0.05\right.$ vs. control, $n=6$ ), but $\mathrm{H}_{2} \mathrm{O}_{2}$ was upregulated in endothelial cells treated with $300 \mu \mathrm{M} \cup \mathrm{A}$ for $24 \mathrm{~h}\left({ }^{*} P<0.05 \mathrm{vs}\right.$. control, $n=6$ ). ${ }^{1} \mathrm{O}_{2}$ and $\cdot$ OH levels were down-regulated in endothelial cells treated with $600 \mu \mathrm{M} \cup \mathrm{A}$ for $24 \mathrm{~h}\left({ }^{\#} P<0.05\right.$ vs. control, $n=6$ ), whereas $\mathrm{O}_{2}^{-}, \mathrm{H}_{2} \mathrm{O}_{2}$, and $\mathrm{ONOO}^{-}$levels were up-regulated in endothelial cells treated with $600 \mu \mathrm{M} \cup \mathrm{A}\left({ }^{\sharp} P<0.05\right.$ vs. control, $\left.n=6\right)$. $\mathbf{b} \mathrm{H}_{2} \mathrm{O}_{2}$ production decreased in epalrestat + HUA cells that were pretreated with epalrestat for 30 min followed by treatment with $600 \mu \mathrm{M} \cup \mathrm{A}$ for $24 \mathrm{~h}$ ( ${ }^{*} P<0.05$ vs. HUA group, $n=6$ ), but ONOO- levels in Epalrestat + HUA cells did not change compared to the HUA group. c Tntracellular H2O2 and total ROS levels were reduced by using PEG-catalase in the high UA cells, and NO production was enhanced in PEG-catalase + high UA cells pretreated with PEG-catalase for 30 min followed by treatment with $600 \mu \mathrm{M} U A$ for $24 \mathrm{~h}\left({ }^{*} P<0.05\right.$ vs. HUA group, $\left.n=6\right)$

changes $[57,58]$. UA possesses the potential to downregulate NO production and induce endothelial injury through at least three mechanisms, namely modulating the eNOS phosphorylation status, potentiating arginase activity, and increasing intracellular superoxide levels [59]. Because UA is a powerful free radical scavenger, we first investigated changes in levels of the major free radicals in the presence of different UA concentrations in the endothelium. The four major cellular ROS components are Mito- $\mathrm{O}_{2}^{--}, \cdot \mathrm{OH},{ }^{1} \mathrm{O}_{2}$, and $\mathrm{H}_{2} \mathrm{O}_{2}$, all of which can be interconverted [38, 60-63]. Here, we observed that under normal UA concentrations $(300 \mu \mathrm{M})$, UA suppresses $\mathrm{O}_{2}^{--}, \cdot \mathrm{OH}$, and ${ }^{1} \mathrm{O}_{2}$ release and slightly increases $\mathrm{H}_{2} \mathrm{O}_{2}$. The slight increase in $\mathrm{H}_{2} \mathrm{O}_{2}$ levels (Fig. 4a) may not be harmful because low $\mathrm{H}_{2} \mathrm{O}_{2}$ concentrations can protect endothelial function $[64,65]$ and affect vasodilation [66]. When the UA concentration was increased to $600 \mu \mathrm{M},{ }^{1} \mathrm{O}_{2}$ and $\cdot \mathrm{OH}$ release remained suppressed, whereas $\mathrm{O}_{2}^{--}$and $\mathrm{H}_{2} \mathrm{O}_{2}$ levels significantly increased. Because $\mathrm{H}_{2} \mathrm{O}_{2}$ is generated from reduced $\mathrm{O}_{2}^{*-}$ by superoxide dismutase (SOD), high UA levels likely did not suppress $\mathrm{O}_{2}^{--}$release but rather stimulated $\mathrm{O}_{2}^{--}$generation. This

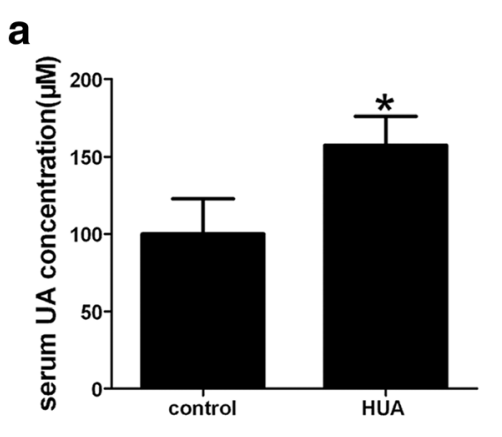

b
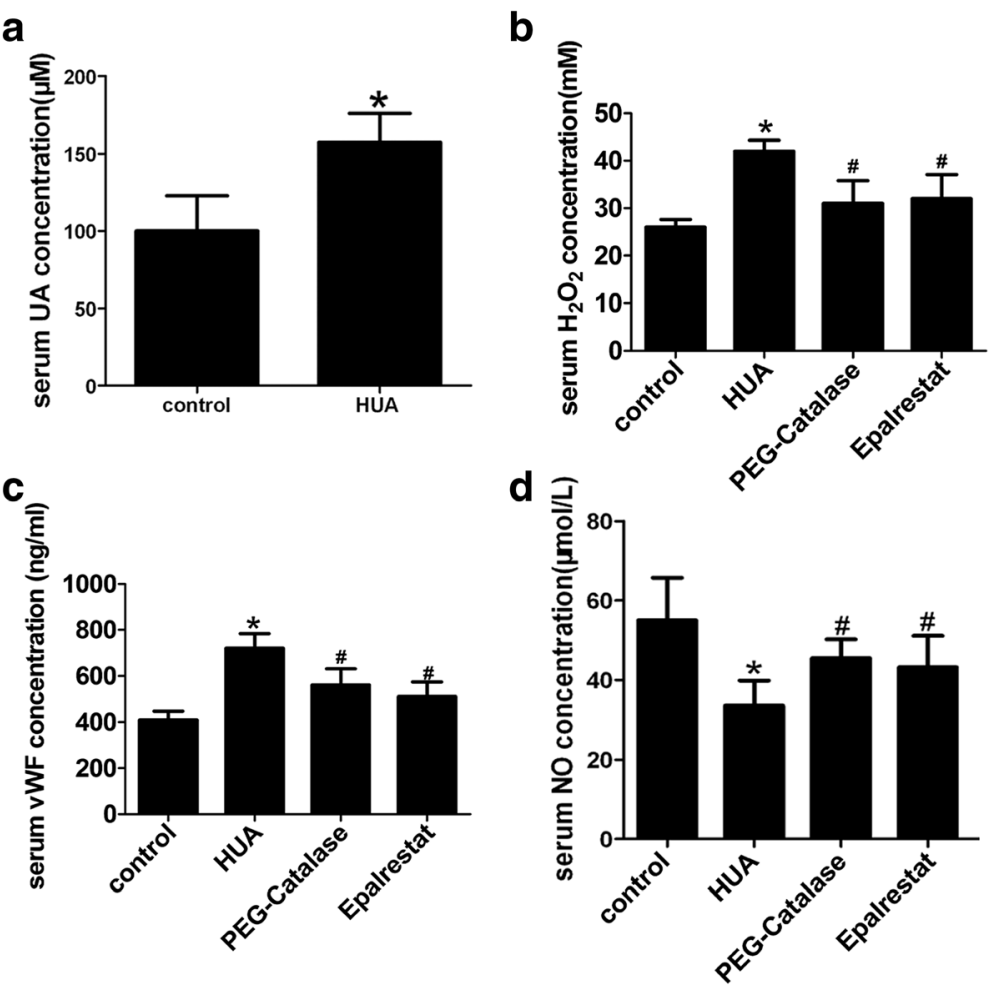

Fig. 5 The AR inhibitor reduced $\mathrm{H}_{2} \mathrm{O}_{2}$ production and protected endothelial function. a After intraperitoneal injection with oxonic acid potassium salt and UA for 10 days, serum UA levels in wild-type C57BL/6 mice increased significantly ( ${ }^{*} P<0.05$ vs. control, $n=6$ ), (b) Serum $\mathrm{H}_{2} \mathrm{O}_{2}$ levels increased in non-treated hyperuricemic mice ( ${ }^{*} P<0.05$ vs. control, $n=6$ ). AfterPEG-catalase or epalrestat treatment, serum $\mathrm{H}_{2} \mathrm{O}_{2}$ levels declined significantly compared to the non-treated hyperuricemic group ( ${ }^{\#} P<0.05$ vs. HUA group, $\left.n=6\right)$. c Serum VWF levels increased in the hyperuricemic mouse model $\left({ }^{*} P<0.05\right.$ vs. control, $\left.n=6\right)$. After treatment with PEG-catalase or epalrastat, serum vWF levels declined significantly compared to the non-treated hyperuricemic group ( $P<0.05$ vs. HUA group, $n=6$ ). d NO levels decreased in the hyperuricemic model ( $* P<0.05$ vs. control, $n=6)$. After treatment with PEG- catalase or epalrastat, serum NO levels increased significantly compared to the non-treated hyperuricemic group (\# $P<0.05$ vs. HUA group, $n=6)$ 
result is similar to previous reports [3, 67]. Although it is not a free radical, we also measured $\mathrm{ONOO}^{-}$levels, which is a highly toxic molecule that can cause harmful effects. Under normal conditions, the $\mathrm{ONOO}^{-}$level remains low due to the low level of $\mathrm{O}_{2}^{*-}$ generation. However, if $\mathrm{O}_{2}^{--}$generation is enhanced, $\mathrm{ONOO}^{-}$production also increases [68-70]. Because UA can scavenge $\mathrm{ONOO}^{-}, \mathrm{ONOO}^{-}$levels decreased in the presence of normal UA concentrations. The increase in $\mathrm{ONOO}^{-}$ levels resulting from high UA treatment was likely due to elevated $\mathrm{O}_{2}^{*-}$ levels. These results suggest that enhanced $\mathrm{O}_{2}^{--}$generation plays a central role in high UAinduced endothelial dysfunction.

Our previous study demonstrated high concentration uric acid could induce AR mRNA and protein expression level of HUVECs [24]. Johnson et al. reported that p38 and ERK44/42 MAPK pathways are activation in rat VSMC incubated with uric acid [71, 72]. Later, they confirmed the activation of p38 and ERK44/42 MAPK pathways were involved in HVSMC and endothelial cells treated with uric acid [12]. In order to try to clarify whether high UA mediate AR expression increase via above signal pathway. We observed AR expression could be repressed when using p38 or MAPK inhibitor respectively, or the organic anion transporter blocker probenecid. It implied that high UA might mediated AR expression via p38/MAPK pathway (Fig. 6). Researchers demonstrated p38 could activate osmotic response element-binding protein/tonicity-responsive enhancerbinding protein (OREBP/TonEBP), transcriptional factors, which bind AR promoter then induce its expression [73]. We also measured the activity of the two protein. Yet in the high concentration uric acid environment, the

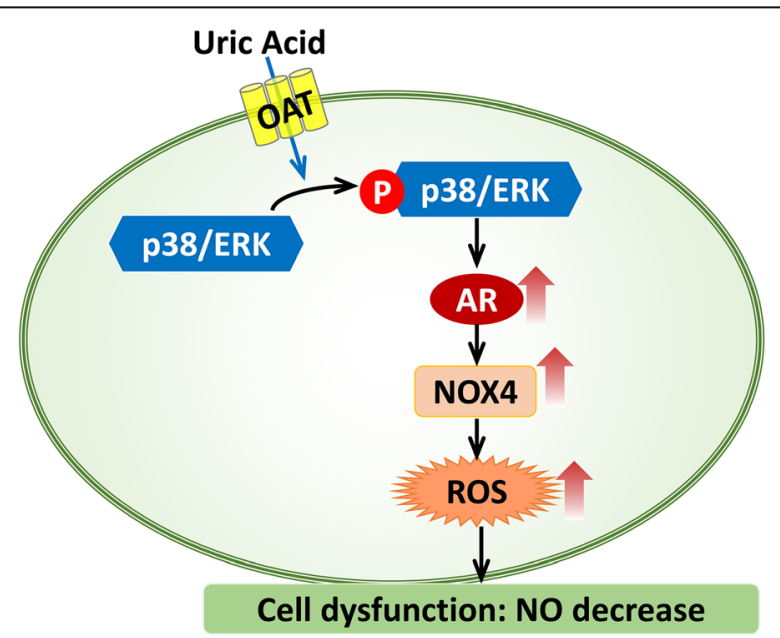

Fig. 6 The mechanism of uric acid inducing endothelial dysfunction. OAT: organic anion transporter. AR: aldose reductase, NOX4: nicotinamide adenine dinucleotide phosphate oxidase 4, ROS: reactive oxygen species, NO: nitric oxide expression or the activity of OREBP/TonEBP did not increase (data was not shown). The mechanism of the elevated $A R$ expression and activity induced by uric acid does not depend on the p38-OREBP/TonEBP. Nishikawa et al. considered that ROS production also can activated AR expression [74]. We observed that ROS produced at early time but AR expression obviously changed at $24 \mathrm{~h}$. Our previous study proved high concentration of uric acid caused abnormal sodium-calcium exchanger of mitochondria then induced the ROS production [14], which will further increase AR expression and these may be locked into a destructive cycle. There might be other pathway mediate ROS production in the high concentration of uric acid.

When an AR inhibitor was added to the high UAtreated HUVECs, total ROS levels significantly decreased, and NO levels recovered. AR-induced ROS production is associated with NADPH [32,33]; our results also suggested the involvement of NOX4 activation, but not NOX2 (Additional file 1). Upon blocking NOX4 with apocynin, ROS levels decreased, and NO levels recovered. When NOX4 was overexpressed In ARknockdown HUVECs overexpressing NOX4 treated with high UA, ROS production and NO levels were the inverse of those resulting from NOX4 overexpression alone. Additionally, the AR inhibitor epalrestat affected $\mathrm{H}_{2} \mathrm{O}_{2}$ but not $\mathrm{ONOO}^{-}$levels and increased NO levels. These results confirm that AR activation plays an important role in high UA-stimulated HUVECs.

The above results suggest that the high UA-induced increased $\mathrm{O}_{2}^{--}$generation was associated with the switch of UA functioning as an antioxidant to a pro-oxidant in vitro. Because $\mathrm{O}_{2}^{--}$is catalyzed to $\mathrm{H}_{2} \mathrm{O}_{2}$ by SOD in vivo, $\mathrm{H}_{2} \mathrm{O}_{2}$ is likely the major contributor to endothelial dysfunction. Additionally, serum UA levels correlate with plasma $\mathrm{H}_{2} \mathrm{O}_{2}$ in preeclampsia [75]. Therefore, blocking AR, reducing $\mathrm{H}_{2} \mathrm{O}_{2}$, or decreasing $\mathrm{O}_{2}^{*-}$ would protect the endothelium from high UA-induced injury. In this study, epalrestat and PEG-catalase recovered NO secretion levels and decreased vWF levels.

Previously, we measured blood pressure in hyperuricemic wild-type mice and reported no difference between the two groups (data not shown). Endothelial dysfunction resulting from hyperuricemia would not impact blood pressure in the two-week model. However, if the duration of exposure to high UA concentrations was extended, the accumulation of endothelial dysfunction would cause artery dysfunction and dysarteriotony. These data are similar to the report by Johnson et al. [51, 76].

\section{Conclusion}

Our study confirmed that the levels of ROS components changed in HUVECs cultured in media containing different UA concentrations. In particular, $\mathrm{H}_{2} \mathrm{O}_{2}$ 
significantly increased in the high UA group compared with the control group. The elevated ROS levels were reversed when AR was inhibited in vivo or in vitro. Thus, the pro-oxidant activity of UA when present at high concentrations likely plays an important role in endothelial dysfunction via AR.

\section{Additional files}

Additional file 1: ROS and NO production induced by uric acid. (PDF $104 \mathrm{~kb}$ )

Additional file 2: NOX2 and NOX4 expression induced by high uric acid. (PDF $107 \mathrm{~kb})$

\section{Abbreviations}

${ }^{1} \mathrm{O}_{2}$ : Singlet oxygen; AR: Aldose reductase; $\mathrm{H}_{2} \mathrm{O}_{2}$ : Hydrogen peroxide; HUVEC: Human umbilical vein endothelial cells; NO: Nitric oxide; NOX: NADPH oxidase; $\mathrm{O}_{2}^{-}$: Superoxide anion; $\mathrm{OH}$ : Hydroxyl radical; ONOO

-: Peroxynitrite; ROS: Reactive oxygen species; SOD: Superoxide dismutase; UA: Uric acid; WWF: von Willebrand factor

\section{Acknowledgements}

This work was carried out and finished at the State Key Laboratory of Kidney Diseases(2011DAV00088).

\section{Funding}

This work is supported by the Chinese National Natural Sciences Foundation (No. 31170810 and 81470949), the Beijing NOVA Program

(Z121107002512078) and by a grant (2013CB530800) from the National Basic Research Program of China (973 Program).

\section{Availability of data and materials}

Not applicable.

\section{Authors' contributions}

Zhiyong Huang and Quan Hong: Acquisition of data, drafting of the article; Xueguang Zhang, Wenzhen Xiao, and Liyuan Wang: Analysis and interpretation of the data, and statistical expertise; Guangyan Cai, Xiangmei Chen and Di Wu: Conception and design of the study. Quan Hong, Xiangmei Chen and Di Wu: obtaining of funding; Shaoyuan Cui, Zhe Feng, Yang LV: Administrative, technical, or logistic support; Shaoyuan Cui and Quan Hong: Provision of study materials; All of authors: final approval of the article.

\section{Authors' information}

Zhiyong Huang, M.D., Quan Hong, M.D., Xueguang Zhang, M.D., WenZhen Xiao, M.D., Liyuan Wang, M.D., Shaoyuan Cui, B.S., Zhe Feng, M.D., Yang Lv, M.D., Guangyan Cai, M.D., Xiangmei Chen, Ph.D \& M.D., Di Wu, M.D.

\section{Competing interests}

The authors declare that they have no competing interests.

\section{Consent for publication}

All of authors content to publication.

\section{Ethical approval and consent to participate} Not applicable.

\section{Author details}

'Department of Nephrology, Chinese PLA General Hospital, Chinese PLA Institute of Nephrology, State Key Laboratory of Kidney Diseases, National Clinical Research Center of Kidney Diseases, Beijing 100853, People's Republic of China. ${ }^{2}$ Department of Nephrology, The 175th Hospital of PLA, Zhangzhou Fujian 36300, People's Republic of China. ${ }^{3}$ Division of Nephrology, Department of Medicine, Icahn School of Medicine at Mount Sinai, New York, NY 10029, USA
Received: 21 January 2016 Accepted: 20 December 2016

Published online: 05 January 2017

\section{References}

1. Wu XW, Muzny DM, Lee CC, Caskey CT. Two independent mutational events in the loss of urate oxidase during hominoid evolution. J Mol Evol. 1992;34:78-84

2. Alvarez-Lario B, Macarron-Vicente J. Uric acid and evolution. Rheumatology (Oxford). 2010:49:2010-5.

3. Sautin YY, Johnson RJ. Uric acid: the oxidant-antioxidant paradox. Nucleosides Nucleotides Nucleic Acids. 2008:27:608-19.

4. Ames BN, Cathcart R, Schwiers E, Hochstein P. Uric acid provides an antioxidant defense in humans against oxidant- and radical-caused aging and cancer: a hypothesis. Proc Natl Acad Sci U S A. 1981;78:6858-62.

5. Spitsin SV, Scott GS, Mikheeva T, Zborek A, Kean RB, Brimer CM, Koprowski $\mathrm{H}$, Hooper DC. Comparison of uric acid and ascorbic acid in protection against EAE. Free Radic Biol Med. 2002;33:1363-71.

6. Chamorro A, Planas AM, Muner DS, Deulofeu R. Uric acid administration for neuroprotection in patients with acute brain ischemia. Med Hypotheses. 2004;62:173-6.

7. Glantzounis GK, Tsimoyiannis EC, Kappas AM, Galaris DA. Uric acid and oxidative stress. Curr Pharm Des. 2005:11:4145-51.

8. Perticone F, Sciacqua A, Perticone M, Arturi F, Scarpino PE, Quero M, Sesti G. Serum uric acid and 1-h postload glucose in essential hypertension. Diabetes Care. 2012;35:153-7.

9. Doherty M. New insights into the epidemiology of gout. Rheumatology (Oxford). 2009;48 Suppl 2:ii2-8.

10. Feig Dl, Kang DH, Johnson RJ. Uric acid and cardiovascular risk. N Engl J Med. 2008:359:1811-21.

11. Alvarez-Lario B, Macarron-Vicente J. Is there anything good in uric acid? QJM. 2011:104:1015-24.

12. Kang DH, Park SK, Lee IK, Johnson RJ. Uric acid-induced C-reactive protein expression: implication on cell proliferation and nitric oxide production of human vascular cells. J Am Soc Nephrol. 2005;16:3553-62.

13. Papezikova L, Pekarova M, Lojek A, Kubala L. The effect of uric acid on homocysteine-induced endothelial dysfunction in bovine aortic endothelial cells. Neuro Endocrinol Lett. 2009:30 Suppl 1:112-5.

14. Hong Q, Qi K, Feng Z, Huang Z, Cui S, Wang L, Fu B, Ding R, Yang J, Chen $X$, Wu D. Hyperuricemia induces endothelial dysfunction via mitochondrial $\mathrm{Na}+/ \mathrm{Ca} 2+$ exchanger-mediated mitochondrial calcium overload. Cell Calcium. 2012;51:402-10

15. Macchi C, Molino-Lova R, Polcaro P, Guarducci L, Lauretani F, Cecchi F, Bandinelli S, Guralnik JM, Ferrucci L. Higher circulating levels of uric acid are prospectively associated with better muscle function in older persons. Mech Ageing Dev. 2008;129:522-7

16. Waring WS, McKnight JA, Webb DJ, Maxwell SR. Uric acid restores endothelial function in patients with type 1 diabetes and regular smokers. Diabetes. 2006:55:3127-32

17. Navarro-Gonzalez JF, Mora-Fernandez C. Inflammatory pathways. Contrib Nephrol. 2011:170:113-23.

18. Ramana KV. ALDOSE REDUCTASE: new insights for an old enzyme. Biomol Concepts. 2011;2:103-14.

19. Kolesnichenko LS, Dykhno lu A, Mantorova NS, Kanevskii AM, Shapiro LA. Activity of enzymes of glutathione metabolism and regulation by CAMP in human tumors. Vopr Onkol. 1987:33:45-50.

20. Sung JK, Koh JH, Lee MY, Kim BH, Nam SM, Kim JH, Yoo JH, Kim SH, Hong SW, Lee EY, et al. Aldose reductase inhibitor ameliorates renal vascular endothelial growth factor expression in streptozotocin-induced diabetic rats. Yonsei Med J. 2010:51:385-91.

21. Hotta N, Kawamori R, Fukuda M, Shigeta Y, Aldose Reductase InhibitorDiabetes Complications Trial Study G. Long-term clinical effects of epalrestat, an aldose reductase inhibitor, on progression of diabetic neuropathy and other microvascular complications: multivariate epidemiological analysis based on patient background factors and severity of diabetic neuropathy. Diabet Med. 2012;29:1529-33.

22. Liu H, Luo Y, Zhang T, Zhang Y, Wu Q, Yuan L, Chung SS, Oates PJ, Yang JY. Genetic deficiency of aldose reductase counteracts the development of diabetic nephropathy in C57BL/6 mice. Diabetologia. 2011;54:1242-51.

23. Morsy MD, Hassan WN, Zalat SI. Improvement of renal oxidative stress markers after ozone administration in diabetic nephropathy in rats. Diabetol Metab Syndr. 2010;2:29. 
24. Zhang Y, Hong Q, Huang Z, Xue P, LV Y, Fu B, Chen X, Wu D. ALDR Enhanced Endothelial Injury in Hyperuricemia Screened using SILAC. Cell Physiol Biochem. 2014;33:479-90.

25. Williamson JR, Chang K, Frangos M, Hasan KS, Ido Y, Kawamura T, Nyengaard JR, van den Enden M, Kilo C, Tilton RG. Hyperglycemic pseudohypoxia and diabetic complications. Diabetes. 1993;42:801-13.

26. Trueblood N, Ramasamy R. Aldose reductase inhibition improves altered glucose metabolism of isolated diabetic rat hearts. Am J Physiol. 1998;275: H75-83.

27. Ramasamy R, Liu H, Oates PJ, Schaefer S. Attenuation of ischemia induced increases in sodium and calcium by the aldose reductase inhibitor zopolrestat. Cardiovasc Res. 1999;42:130-9.

28. Hwang YC, Kaneko M, Bakr S, Liao H, Lu Y, Lewis ER, Yan S, li S, Itakura M, Rui $L$, et al. Central role for aldose reductase pathway in myocardial ischemic injury. FASEB J. 2004;18:1192-9.

29. Iwata K, Matsuno K, Nishinaka T, Persson C, Yabe-Nishimura C. Aldose reductase inhibitors improve myocardial reperfusion injury in mice by a dual mechanism. J Pharmacol Sci. 2006;102:37-46.

30. Obrosova IG, Minchenko AG, Vasupuram R, White L, Abatan Ol, Kumagai AK, Frank RN, Stevens MJ. Aldose reductase inhibitor fidarestat prevents retinal oxidative stress and vascular endothelial growth factor overexpression in streptozotocin-diabetic rats. Diabetes. 2003;52:864-71.

31. Chung SS, Ho EC, Lam KS, Chung SK. Contribution of polyol pathway to diabetes-induced oxidative stress. J Am Soc Nephrol. 2003;14:S233-6.

32. Alexiou P, Pegklidou K, Chatzopoulou M, Nicolaou I, Demopoulos VJ. Aldose reductase enzyme and its implication to major health problems of the 21(st) century. Curr Med Chem. 2009;16:734-52.

33. Dunlop M. Aldose reductase and the role of the polyol pathway in diabetic nephropathy. Kidney Int Suppl. 2000;77:S3-12.

34. Ramana KV, Srivastava SK. Aldose reductase: a novel therapeutic target for inflammatory pathologies. Int J Biochem Cell Biol. 2010;42:17-20.

35. Wermuth B, von Wartburg JP. Aldose reductase from human tissues. Methods Enzymol. 1982;89 Pt D:181-6.

36. Spycher SE, Tabataba-Vakili S, O'Donnell VB, Palomba L, Azzi A. Aldose reductase induction: a novel response to oxidative stress of smooth muscle cells. FASEB J. 1997;11:181-8.

37. Yang Z, Xiaohua W, Lei J, Ruoyun T, Mingxia X, Weichun H, Li F, Ping W, Junwei Y. Uric acid increases fibronectin synthesis through upregulation of lysyl oxidase expression in rat renal tubular epithelial cells. Am J Physiol Renal Physiol. 2010;299:F336-46.

38. Bedard K, Krause KH. The NOX family of ROS-generating NADPH oxidases: physiology and pathophysiology. Physiol Rev. 2007;87:245-313.

39. Basuroy S, Bhattacharya S, Leffler CW, Parfenova H. Nox4 NADPH oxidase mediates oxidative stress and apoptosis caused by TNF-alpha in cerebral vascular endothelial cells. Am J Physiol Cell Physiol. 2009;296:C422-32.

40. Lambeth JD. NOX enzymes and the biology of reactive oxygen. Nat Rev Immunol. 2004:4:181-9.

41. Wesseling JG, de Ree JM, Ponnudurai T, Smits MA, Schoenmakers JG. Nucleotide sequence and deduced amino acid sequence of a Plasmodium falciparum actin gene. Mol Biochem Parasitol. 1988;27:313-20.

42. Kirilov G, Zacharieva S, Alexandrov AS, Lozanov V, Mitev V. Increased plasma endothelin level as an endothelial marker of cardiovascular risk in patients with active acromegaly: a comparison with plasma homocysteine. Methods Find Exp Clin Pharmacol. 2009;31:457-61.

43. Vischer UM. von Willebrand factor, endothelial dysfunction, and cardiovascular disease. J Thromb Haemost. 2006:4:1186-93.

44. Lip GY, Blann A. von Willebrand factor: a marker of endothelial dysfunction in vascular disorders? Cardiovasc Res. 1997;34:255-65.

45. Bobulescu IA, Moe OW. Renal transport of uric acid: evolving concepts and uncertainties. Adv Chronic Kidney Dis. 2012;19(6):358-71.

46. Jia G, Habibi J, Bostick BP, Ma L, DeMarco VG, Aroor AR, Hayden MR, Whaley-Connell AT, Sowers JR. Uric Acid promotes left ventricular diastolic dysfunction in mice fed a Western diet. Hypertension. 2015;65: 531-9.

47. Gersch C, Palii SP, Kim KM, Angerhofer A, Johnson RJ, Henderson GN. Inactivation of nitric oxide by uric acid. Nucleosides Nucleotides Nucleic Acids. 2008;27:967-78.

48. Obermayr RP, Temml C, Gutjahr G, Knechtelsdorfer M, Oberbauer R, KlauserBraun R. Elevated uric acid increases the risk for kidney disease. J Am Soc Nephrol. 2008;19:2407-13.
49. Alper Jr AB, Chen W, Yau L, Srinivasan SR, Berenson GS, Hamm LL. Childhood uric acid predicts adult blood pressure: the bogalusa heart study. Hypertension. 2005;45:34-8.

50. Johnson RJ, Kang DH, Feig D, Kivlighn S, Kanellis J, Watanabe S, Tuttle KR, Rodriguez-Iturbe B, Herrera-Acosta J, Mazzali M. Is there a pathogenetic role for uric acid in hypertension and cardiovascular and renal disease? Hypertension. 2003;41:1183-90.

51. Kang DH, Nakagawa T, Feng L, Watanabe S, Han L, Mazzali M, Truong L, Harris R, Johnson RJ. A role for uric acid in the progression of renal disease. J Am Soc Nephrol. 2002;13:2888-97.

52. Becker BF, Reinholz N, Leipert B, Raschke P, Permanetter B, Gerlach E. Role of uric acid as an endogenous radical scavenger and antioxidant. Chest. 1991:100:176S-81.

53. Landmesser U, Merten R, Spiekermann S, Buttner K, Drexler H, Hornig B. Vascular extracellular superoxide dismutase activity in patients with coronary artery disease: relation to endothelium-dependent vasodilation. Circulation. 2000;101:2264-70.

54. Kanellis J, Kang DH. Uric acid as a mediator of endothelial dysfunction, inflammation, and vascular disease. Semin Nephrol. 2005;25:39-42.

55. Duan $X$, Ling F. Is uric acid itself a player or a bystander in the pathophysiology of chronic heart failure? Med Hypotheses. 2008;70:578-81.

56. Kutzing MK, Firestein BL. Altered uric acid levels and disease states. J Pharmacol Exp Ther. 2008;324:1-7.

57. Wink DA, Hines HB, Cheng RY, Switzer CH, Flores-Santana W, Vitek MP, Ridnour LA, Colton CA. Nitric oxide and redox mechanisms in the immune response. J Leukoc Biol. 2011;89:873-91.

58. Yokoyama M, Hirata K. Endothelial nitric oxide synthase uncoupling: Is it a physiological mechanism of endothelium-dependent relaxation in cerebral artery? Cardiovasc Res. 2007;73:8-9.

59. Papezikova I, Pekarova M, Kolarova H, Klinke A, Lau D, Baldus S, Lojek A, Kubala L. Uric acid modulates vascular endothelial function through the down regulation of nitric oxide production. Free Radic Res. 2013:47:82-8.

60. Droge W. Free radicals in the physiological control of cell function. Physiol Rev. 2002;82:47-95.

61. Nathan C, Ding A. SnapShot: Reactive Oxygen Intermediates (ROI). Cell. 2010;140:951. e952.

62. Finkel T, Holbrook NJ. Oxidants, oxidative stress and the biology of ageing. Nature. 2000:408:239-47.

63. Powers SK, Jackson MJ. Exercise-induced oxidative stress: cellular mechanisms and impact on muscle force production. Physiol Rev. 2008;88: 1243-76.

64. Faraci FM. Hydrogen peroxide: watery fuel for change in vascular biology. Arterioscler Thromb Vasc Biol. 2006;26:1931-3.

65. Zanetti M, Katusic ZS, O'Brien T. Adenoviral-mediated overexpression of catalase inhibits endothelial cell proliferation. Am J Physiol Heart Circ Physiol. 2002;283:H2620-6.

66. Thengchaisri N, Shipley R, Ren Y, Parker J, Kuo L. Exercise training restores coronary arteriolar dilation to NOS activation distal to coronary artery occlusion: role of hydrogen peroxide. Arterioscler Thromb Vasc Biol. 2007;27: 791-8.

67. Khosla UM, Zharikov S, Finch JL, Nakagawa T, Roncal C, Mu W, Krotova K, Block ER, Prabhakar S, Johnson RJ. Hyperuricemia induces endothelial dysfunction. Kidney Int. 2005;67:1739-42.

68. Radi R, Peluffo G, Alvarez MN, Naviliat M, Cayota A. Unraveling peroxynitrite formation in biological systems. Free Radic Biol Med. 2001; 30:463-88.

69. Pacher P, Beckman JS, Liaudet L. Nitric oxide and peroxynitrite in health and disease. Physiol Rev. 2007:87:315-424.

70. Gersch C, Palii SP, Imaram W, Kim KM, Karumanchi SA, Angerhofer A, Johnson RJ, Henderson GN. Reactions of peroxynitrite with uric acid: formation of reactive intermediates, alkylated products and triuret, and in vivo production of triuret under conditions of oxidative stress. Nucleosides Nucleotides Nucleic Acids. 2009;28:118-49.

71. Kanellis J, Watanabe S, Li JH, Kang DH, Li P, Nakagawa T, Wamsley A, Sheikh-Hamad D, Lan HY, Feng L, Johnson RJ. Uric acid stimulates monocyte chemoattractant protein-1 production in vascular smooth muscle cells via mitogen-activated protein kinase and cyclooxygenase-2. Hypertension. 2003;41:1287-93.

72. Watanabe S, Kang DH, Feng LL, Nakagawa T, Kanellis J, Lan H, Mazzali M, Johnson RJ. Uric acid, hominoid evolution, and the pathogenesis of saltsensitivity. Hypertension. 2002;40:355-60. 
73. Ko BC, Lam AK, Kapus A, Fan L, Chung SK, Chung SS. Fyn and p38 signaling are both required for maximal hypertonic activation of the osmotic response element-binding protein/tonicity-responsive enhancer-binding protein (OREBP/TonEBP). J Biol Chem. 2002;277:46085-92.

74. Nishikawa T, Edelstein D, Brownlee M. The missing link: a single unifying mechanism for diabetic complications. Kidney Int Suppl. 2000;77:S26-30

75. Tsukimori K, Yoshitomi T, Morokuma S, Fukushima K, Wake N. Serum uric acid levels correlate with plasma hydrogen peroxide and protein carbonyl levels in preeclampsia. Am J Hypertens. 2008;21:1343-6.

76. Mazzali M, Hughes J, Kim YG, Jefferson JA, Kang DH, Gordon KL, Lan HY, Kivlighn S, Johnson RJ. Elevated uric acid increases blood pressure in the rat by a novel crystal-independent mechanism. Hypertension. 2001;38:1101-6.

Submit your next manuscript to BioMed Central and we will help you at every step:

- We accept pre-submission inquiries

- Our selector tool helps you to find the most relevant journal

- We provide round the clock customer support

- Convenient online submission

- Thorough peer review

- Inclusion in PubMed and all major indexing services

- Maximum visibility for your research

Submit your manuscript at www.biomedcentral.com/submit
Biomed Central 